\title{
GENEALOGY OF POLITICAL THEATRE IN POST-SOCIALISM. FROM THE ANTI-“SYSTEM" NIHILISM TO THE ANTI-CAPITALIST LEFT 1
}

\author{
DAVID SCHWARTZ ${ }^{2}$
}

\begin{abstract}
What have been the conditions of production for a political theatre to appear in post-1990s Romania? How and why contemporary theatre in Romania ended up ignoring or dismissing the leftwing, engaged or militant theatrical movements active before 1945? Why local theatre history and theory entirely obliterated, also, the politically-engaged theatre forms active during communism itself? What kind of tradition forms the contemporary political theatre, what is the politics that informs their working practices and collaborations, how do the artists engage with the groups they choose to give voice and with the audience? Using a broad and on-purpose multi-faceted definition of political theatre, the article focuses on theatre artists, practices and performances that question capitalism as a social and power structure, sometimes from an intersectional perspective, but always framing this criticism in a class approach. Largely a practice-based analysis, the text gives a comprehensive on-going history of a strong performative movement and its challenges, from the representational strategies and the financial and positioning issues to the scarcity of critical covering and reviewing and the extending of an (opposite) political engagement in the mainstream theatre in Romania.
\end{abstract}

Key words: political theatre, leftist movements, contemporary playwriting

\section{Context. About the "engaged theatre"}

During the last 20 years, the political, openly militant direction has coagulated and developed slowly but surely in the local theatrical space. The engagement in political activism or the stage representation of certain marginal perspectives were perceived in the early 2000 s as almost heretical - even the simple curses spoken on the stage were seen as acts of sullying, of invading the theatre space (with capital T), by the "suburban" language, characteristic,

1 Translated from Romanian by Iulia Popovici.

2 Theatre director, email: davey_schwartz@yahoo.com. 
isn't it?, only to the popular, "uneducated" classes. Today, however, less than a generation apart, references to protests or explicit support, through theatrical discourse, of various political parties and movements has become "fashionable", including among the most conservative and elitist directors - see their recent rallying, with all their "theatrical" weapons, on the anti-PSD ${ }^{3}$ right, in shows such as The Forest of the Hanged, directed by Radu Afrim in 2018, or Richard III, directed by Andrei Șerban in 2018. But I would say that the theatre assumed by the left, critical of capitalism, self-reflective in its internal hierarchies or in the process of self-education of the artistic collective, and with the ambition to contribute to the revealing and shaming of oppressive social-economic structures has also gained enough ground.

The present text aims to briefly outline the genealogy and main directions of the social-political theatre with a leftist ethos, the structuring of this theatre movement critical towards the post-socialist capitalist system. The perspective will be an assumed one, from the "inside", of a direct participant in the coagulation of the local political theatre. As such, with all the author's effort to distance himself, I think that the text should be viewed not as an objective analysis and in no case an exhaustive one, and rather as a reading from within, a challenge to critics and historians, both from the cultural sphere and from the more general leftist field, to go deeper into the subject.

In theatre reviewing, three people constantly noticed and analysed the theatre approaches critical to capitalism and tried to do so including forms of political reading -Mihaela Michailov, Iulia Popovici and Oana Stoica. In recent years, people from the field of journalism, critical theory or social sciences have also written about one project or another - the most consistently, Maria Cernat, but also Dora Constantinovici, Claude Karnoouh, Veronica Lazăr, Bogdan Popa, Adrian Schiop. Some important artists have analysed and theorized their own efforts in academic works - Gianina Cărbunariu (2011), Bogdan Georgescu (2013), Radu Apostol (2018). For my part, I wrote a doctoral thesis focused on the relationship between artists and various subaltern groups with whom I worked in political theatre projects (Schwartz 2016). Finally, as far as I know, the only steps with the ambitions (and the success) of historicizing and analysing the various aspects of the context of the emergence and reproduction of the local political theatre belong to Iulia Popovici (especially in The Elephant in the Room. A Guide to the Independent Theatre in Romania, 2017; but also in her studies in Teatrul.ro. 30 New Names, edited by Oltița Cântec, 2019) and Cristina Iancu (The Condition of the Romanian Dramatic Text After 1989, PhD thesis, 2019). The works of Popovici and Iancu are very consistent and established in

3 Social Democratic Party. 
a social-political context, with a critical approach, which takes into account the material and production conditions, aspects very relevant for the development of the political theatre, as well as the contribution of the actors and actresses to the work process in the documentary theatre, or the various declinations of the role of the dramatic author in the playwriting (and the performance) as assumed by the left developed during 2010-2015. But for the time being, none has exclusively and explicitly dealt with the analysis of the theatre critical towards capitalism after $1989^{4}$.

The longer-term history of the local political theatre, although complex, contradictory and marked by interesting artistic, but especially political figures and movements, is still extremely little known and studied. The reasons are multiple and go beyond the subject of the present text, but this lack of interest in local art criticism and theory for the left-wing (workers', proletarian, associated with trade unions and socialist/communist parties) theatre movements is vital to understanding the configuration and patterns of the relatively strong movement of the social-political theatre affirmed after 2000.

During the interwar period, numerous interesting examples of militant artists and groups of popular theatre, proletarian theatre, theatre made for workers and/or with workers are documented. Some of the most important playwrights of the time are involved with popular theatre - Victor Ion Popa runs the "Work and good will" theatre for mass education, created in 1938 at the initiative of the then minister of labour and social protection, the leftist sociologist Mihai Ralea (Popovici, 2017, b). The best-known Yiddish theatre director, Iacob Sternberg, experiments with working-class non-professional actresses in the Bukarester Idișe Teater Studie shows (Bercovici, 1982). Surrealist artist Max Hermann (Maxy) collaborates with Sternberg on the scenography of his political shows (Crăciun, 2016). Bernard Lebli assembles, again with non-professional actors, with workers, The Lower Depths by Maxim Gorki. An Alba-Iulia leader of the (illegal) Communist Party, Dumitru Ciumbrudean, writes and publishes (of course, illegally) the play The Bourgeois of the Time - A Social Satire in XI Frames. Director Izo Șapira, originally from Cernăuți, leads a theatre Agit-prop brigade on the front, him being enlisted in the Republican troops of the Spanish Civil War. Immediately after August 23, 1944, Scarlat Calimachi published a documentplay, probably written during the war, about the pogrom in Bucharest. And

4 Iulia Popovici's texts (in particular the chapters "Gianina Cărbunariu - The long way to a theatre of the present" and "How David Schwartz «invented» an independent theatre", in Cîntec, 2019) make a consistent analysis of the aesthetic proposals of certain political theatre approaches. Because there is this precedent, but especially because my intrinsic subjectivity prevents me from a formal fertile (self) analysis, the present text will only marginally deal with the varied aesthetics of the local political theatre, proposing rather a historical-political perspective. 
the list can go on. Although some of these authors become important public figures after the installation of the socialist regime, there is no structured and complete recovery of the history of the interwar theatre. As Iulia Popovici $(2017$, b) observes very well in what is, as far as I know, the only article on the interwar proletarian theatre published after 1989, it is possible that the most complete source for the history of this theatre is the State's Siguranța - the political police who was diligently pursuing the illegal activity of people such as Ciumbrudean or Lebli. In this context, and given the total lack of interest, in the theatre criticism of the years 1990-2000, for the subject, it is natural that the first to notice the existence of a workers', left-wing, local theatre are historians studying the period (Mihai Burcea or Marius Rotar - so far, they have not published studies and research on the subject, only documents on Facebook).

In the socialist period, the situation changes, as expected, by 180 degrees. From an eccentric exception and experiment of the socialist militants, who risked their freedom by practicing it, the proletarian theatre is now spreading all over the country: in factories, agricultural cooperatives, educational institutions and cultural centres, thousands of amateur theatre groups, of artistic Agitprop brigades or vaudeville theatres are set up, according to the Soviet model. But the history of this enormous mass movement, its internal contradictions and differences, its nuances and complexities, have also remained completely unexplored for the time being (Schwartz, 2016). From the personal, collateral research that we have undertaken in different working environments, the image of artistic brigades and propaganda shows is much more complex than in the usual anti-communist imaginary. Miners from the Jiu Valley told me not only that these activities were generating group cohesion, fun or relaxation, but also that they were pretexts to break the rigors of official politics - for example, within the artistic brigades they sang carols, including religious carols (Schwartz, 2016; Michailov et al., 2017). In countries such as the Soviet Union/Russia, Cuba or Nicaragua, popular theatre movements have been studied very seriously and their contribution to the artistic and political development is recognized and discussed in detail. Unfortunately, locally, the history of the largest workers' theatre experiment, on the left, addressed primarily to subaltern groups, uninteresting for much of the theatre criticism, has remained completely unknown.

Thus, although when following the texts, it is obvious that in the famous literary criticism polemic of the 1880s, between the "art for art's sake" and "art with a tendency" (engaged art), Constantin Dobrogeanu-Gherea, a follower of the latter, won the match with his opponent, Titu Maiorescu (Gherea, 1956), one hundred years later it proves that Maiorescu actually won the victory "at the green table". In the first years after the defeat of the socialist system, the 
theory of art for art's sake, of the supremacy of aesthetics in front of the political or the social, was undoubtedly hegemonic. This leads to a contradiction that is as blatant as it is convenient: in the 1990s, society was restructured, the resources, the means of production, the public goods and spaces were privatized, the economic and social situation of workers and peasants deteriorated, the economy contracted, social and inter-ethnic conflicts erupt violently (Florian, 1997; Pasti, 2006; Ban, 2014). But all this time, the theatre directors, especially the most important and the most successful ones, are almost exclusively concerned with formal experiments. And the theatre criticism values and validates performances first of all according to a formalist, anti-materialist aesthetic, in which the subject, the content and the message are at best secondary, and the conditions of production completely devoid of interest. In the same direction, the contemporary Romanian plays (which in the socialist period occupied an important place in the repertories of theatres) are now almost completely evacuated, the young playwrights are few and marginal, and the social and political subjects find their place with difficulty (Iancu, 2019). When, in the texts of some playwrights of the period, there are references to the problems of the post-socialist "transition", they are generally treated in a miserabilist key, underlining the material and moral degradation of the society, degradation closely linked to the "communist heritage" - it is the case of plays by otherwise very stylistically different authors such as Matei Vișniec, Radu Macrinici, Valentin Nicolau or Alina Nelega. A vision somewhat similar to the paradigm conveyed in cinema by Lucian Pintilie or Mircea Daneliuc and in literature by a writer otherwise interesting for his social radiography of the period, Radu Aldulescu (not accidentally, a screenwriter for Pintilie's film, Terminus Paradis). Aldulescu states it clearly: "Communism was an evil that left behind a greater evil" (Aldulescu, 2012, 4th cover). In other words, guilty for the degradation of life and the destruction of social structures and relations is not the neoliberal "reform", it is not the new capitalist order, but, on the contrary, "the legacy of the old regime". I would not insist on this paradigm, if it were not important for two reasons: on the one hand, it is both the expression and the cornerstone for the lack of legitimacy of the left in the public sphere, including in the theatre; on the other hand, in direct connection and perhaps more importantly, it has left deep traces including in the vision and practice of the first socialpolitical theatre authors after 2000 . As in the sphere of critical theory, literary criticism or political commentary, in order to have relative credibility, assuming an even minimal social perspective, likely to be considered "from the left", had to come initially with the condemnation of real socialism as illegitimate and an exclusive generator of suffering. 


\section{Precursors. The return to realism and the germs of social criticism}

Historically speaking, before 1945, the leftist discourse and movements were in any case quite reduced in Romania, at least in comparison with the neighbouring countries (Hungary, Serbia, even Bulgaria and, of course, the Soviet Union). The reasons are diverse and most probably relate to a number of factors in which poor industrialization, land fragmentation and lack of collective management in agriculture, very low education level of the population (high illiteracy, small number of educational institutions, etc.) as well as the anticommunist/anti-socialist violence of repressive structures (army, gendarmerie, secret police) played essential roles. Local intellectuality and artistic intelligentsia, especially the more visible and connected to state's resources, was also at odds with the tradition of neighbouring countries. Even during the socialist period, after the short Stalinist/internationalist parenthesis, the intellectual and artistic elite returned, in large part, to the nationalist, conservative discourse, even with anti-communist valences (see for example the recuperation of the interwar political and cultural elites after 1970). Which explains, as I said previously, the determined reluctance to the social dimension of art and the lack of interest in the history of militant political theatre after 1989. Considering this course, how can one explain the decidedly left-wing, militant, turn that a good part of the independent theatre (and not exclusively) has taken, to which a number of the most relevant artists and artists for the post-2000 period have aligned? 5

My hypothesis is that the explanation has an important material dimension - the historical and production conditions in the artistic field, of course conjugated with certain elements of contingency (first of all, the Western cultural and institutional influence) have largely determined the movement to the left (or at least the ambitions, disputes and controversies in relation to the social-political system) of many artists and collectives. From my point of view (somewhat in line with the approach in Iancu, 2019), the first local play that changes the paradigm from the miserabilist, anti-communist and self-colonizing vision, to a possible social critique of the present system is When I Want to Whistle, I Whistle, written by Andreea Vălean in 1997. The play fictionalizes the author's personal experience as a sociology student in practice in a juvenile penitentiary and has a classic structure and a simple premise: a young student comes to interview juvenile criminals, in order to "improve their conditions";

5 See for example, the volume Theatre.ro 30. New names, edited by Oltița Cîntec (Timpul Publishing House, 2019), where at least half of the persons and groups discussed emphasize the socialpolitical dimension of the theatre they practice. 
she faces a harsh world, with very strict hierarchies, in which the strongest is the one who owns the most resources and does the best, and the poorest and most vulnerable is the others' slave. An x-ray of the capitalist "transition" society concentrated in the micro-universe of the penitentiary. Initially, the play leaves the impression that it doesn't lack anti-communist nuances - the guardian deplores the "order" in the socialist society, in which the militiaman had power and a monopoly on violence, in contrast to the "human rights" chaos for juvenile delinquents, which would make them take too many liberties. Until the end, however, we are forced to note that the rigidity and "iron hand" of the "school of correction" were replaced by a kind of "law of the jungle", in which a poor and neuro-atypical teenager of rural origins can be put behind bars for stealing a horse cart and no escape dream is actually possible. The play also captures the tension between the new NGO environment of "assistance for vulnerable categories", and the concrete realities in the field. Two features of the play are of particular interest to me, as they represent nodes for the subsequent direction of the socially engaged theatre. First of all, it is probably the first play about the post-socialist present that treats its oppressed characters with warmth, empathy and candour, explaining, with a careful analysis of the biographies and social structures they come from, the systemic logic that governs their situation and behaviour. This lesson of empathy, of the re-humanization of the various subaltern groups stigmatized in the post-socialist public discourse, will be a constant and important mark of the leftist political theatre efforts. Secondly, the play has a certain nihilism that will become even more prevalent in the theatre with social aims, at least until the moment of 2010, if not even later. Finally, the three young people, who had taken the student hostage and hoped that they could escape from the penitentiary and the country, die poisoned, after narrating each of their escape dreams.

This pessimism, specific to many forms of realism (not just in the theatre), according to which "there is no escape", "the situation is without exit", will be taken uncritically by the following generations, including in some productions by teams in which I was involved. After a first staging in Iași, Andreea Vălean's play was staged by Theodor Cristian Popescu at the National Theatre in Târgu-Mureș in 1998. This second production had a considerable success at the time - it was invited and acclaimed at theatre festivals in Sibiu and Bucharest, it launched at least two artists later renowned in the local public theatre - the actor Sorin Leoveanu and the musician Ada Milea. The entire staging in TârguMureș marked a (probably) first experience of leaving the comfortable space of the theatre and the audience: it was performed, with post-show discussions, at the penitentiary in Târgu-Mureș for an audience consisting entirely of prisoners and security staff (Runcan, 2010). Thus, this text also produces the first attempt 
to approach (and involve) the subaltern groups which much of the political theatre subsequently had the ambition to speak about. It is the first, timid sign of a return to the ideas and practices of a theatre that is aimed at other audiences as well as those from the educated middle class. ${ }^{6}$

The next turning point will be represented by the performances directed by Radu Apostol at the "Ion Creangă" theatre, Home (after a text by Liudmila Razumovskaia). Here, the political potential does not hold so much in the text itself as in the director's choice to work with homeless children, who perform in the production, alongside two acting students. For the first time after 1989, on the stage of a state theatre, there are non-professional actors, from an ultraoppressed group (teenagers living in the streets) who talk about the problems they are facing. The experience is transformative not only for the social-political theatre, but also for the director, who will constantly mention the production as a turning point in his career (Apostol, 2018; Cîntec, 2019), for the "official" sphere of the Romanian theatre (Apostol received the UNITER award for debut in 2002, for the directing of Home), but, very important, for the teenagers concerned. As Florian Voda, one of the homeless youths who performed in the show, says ${ }^{7}$ :

I remember that emotion in Home, when I saw people in the first three rows with tears in their eyes and I felt that our story got somewhere, that we said: «Look, life is about this, about the children in the street next to that you pass by daily and seem to have no chance. See how things go?

6 It should be mentioned that the practice of involving in a performance, at least as an active spectator, the social group in question had already been experienced by Theodor Cristian Popescu also a year before, in the production of Children of a Lesser God (Company 777, Sounds of Progress and the Odeon Theatre, 1997), where people with hearing impairments participated in the rehearsals and the performance (see Theodor Cristian Popescu, Surplus of People or Surplus of Ideas. The Pioneers of the Independent Movement in the Romanian Theatre After 1989, Eikon Publishing House, 2012). But there the involvement of the community came from an artistic necessity - it was very difficult for a team of artists in which nobody had hearing impairments to understand, learn and assume the situations and experiences of such people, without directly documenting them. However, in the case of the performance with When I Want to Whistle, I Whistle in the penitentiary, the decision was strictly a political one, which aimed at the social impact of the production.

7 However, from the interview with Florian Vodă, conducted by Mihaela Michailov in 2015, almost 15 years after the premiere, we can draw one of the hardest conclusions valid almost universally for the local contemporary political theatre: that taking part in a theatre performance, although transformative at the personal level, for intellectual and social development, and even, in the best cases, for the politicization of the oppressed group or persons, almost never leads to the concrete change of the material conditions - social and economic - in which people live. Thus, with rare exceptions, the stake remains primarily at the level of influencing the public sphere, at the level of transforming perceptions and ideas, in the hope of contributing to the creation of a politically conscious critical mass. 
GENEALOGY OF POLITICAL THEATRE IN POST-SOCIALISM. FROM THE ANTI-“SYSTEM” NIHILISM TO THE ANTI-CAPITALIST LEFT

That's how they stay ... let's change a little! What do you say? You can't always ignore certain realities!»" (Vodă in Michailov, 2015).

Apostol's performance will remain a rather singular example of fruitful collaboration between artists and an oppressed group, with the aim of selfrepresentation of the latter, until more than six years, in the projects of the Offensive of Generosity in Rahova-Uranus. Together with Vălean and two other generation colleagues, Alexandru Berceanu and Gianina Cărbunariu, supported by Nicolae Mandea ${ }^{8}$, professor at U.N.A.T.C. Bucharest, Apostol founded in 2000 the dramAcum group, which aims to generate and promote contemporary Romanian dramaturgy. Within dramAcum, they discovered some of the playwrights who will play a central role in the development of the social-political theatre (firstly Bogdan Georgescu and Mihaela Michailov, but also Peca Ștefan or Vera Ion). The most incisive social approach remains that of Gianina Cărbunariu, preoccupied from her very first texts with the criticism of the most serious problems of capitalist society. Stop the Tempo!, 2001, is about the anti-consumerist revolt of three middle-class young people, who do not find their place (sometimes not even a job) in a Bucharest of excessive consumption (drinking, music, drugs, "fun"). mady-baby.edu, 2003, talks about human trafficking, juvenile prostitution and the major difficulties of Romanian immigrants' integration in the West.

The performances, also directed by Cărbunariu, had a major impact on the generation of future directors and playwrights, a generation of which I was a part. mady-baby.edu surprised us both by the hyper-realistic, super-tough and very authentic critical analysis of the immigrant condition, and by the counterpoint to this realism of a poetic dimension. For those of us who were students then, it was a lesson on how to make theatre with minimal financial resources, with a strong social-political message, one that provokes emotion and invites to reflection and debate. Looking at the distance of almost 20 years of political theatre and political self-education, Cărbunariu's first two texts, as well as the texts of colleagues discovered in dramAcum competitions (for example Vitamins by Vera Ion, a deconstruction of the family dependent on television and the media, or With a Little Help From My Friends by Maria Manolescu, about teenagers' conflicts

8 Nicolae Mandea will have a decisive role (from the point of view of clarifying the concepts, methodology and means of implementation) also in the emergence of the Offensive of Generosity, the initiative of social intervention through theatre in the Rahova-Uranus neighborhood described in detail below, as well as in the education, within the university, of many artists who assume a political discourse - Alexandra Badea, Gianina Cărbunariu, Bogdan Georgescu, Vera Ion, Ioana Păun, Catinca Drăgănescu. As far as I'm concerned, I owe him a great deal in the interest for the socially engaged theatre and the beginnings of my political education in a left-wing direction. 
and issues), they propose a rather disarticulated revolt, without a specific target and without proposing any way out. Not so much a revolution for establishing a new social order, but rather the anger in the face of any order or attempt to order, to establish the society. A nihilistic approach (present only as an idea in Andreea Vălean's 1997 text), sceptical of any positive political project, critical of both the socialist past and the capitalist present, which could only put the society on the whole on fire. Something that Professor Nicolae Mandea, the supporter and co-founder of dramAcum, called, in a postshow discussion, "anarchic theatre".

This position also came with an often explicit refusal to offer solutions or to get involved in a political project, a position that rather believed in Chekhov's idea that the theatre should "not give answers, but ask questions" than in Brecht's imperative that art should "not mirror the world, but transform it." This, after all, fundamental scepticism towards politics (not only in the strict sense of mistrust of parties, but even in the sense of mistrust in the validity of a certain political project, even assumed by the left), came very possible from the spirit of absolute mistrust with respect to any societal project, and especially to structures and institutions, characteristic of the $1990 \mathrm{~s}^{9}$. Of course, from this heterogeneous group united by the anger and the anti-systemic, but not ideologically assumed, revolt, there were to later appear militant theatre projects (such as those initiated by Bogdan Georgescu, but also productions by the dramAcum founders themselves), but also assumed visions of the extreme right, like those of the poet Marius Ianuș (whose poems are used in Stop the Tempo!).

In summary, I would say that the germs of the constituent elements of the local leftist political theatre appeared between 1997-2002 and all these elements are related to people from the dramAcum team (especially Radu Apostol, Gianina Cărbunariu and Andreea Vălean). These would be: the reintroduction of realism, with documentary valences, as a legitimate, necessary and emergent method of constructing the dramatic text; the focusing on groups and categories oppressed in the new capitalist order, on the losers of the post-socialist "transition" and their active involvement as audience and participants/co-creators of the performance; a spirit of revolt and anger in equal measure to the structural injustices of society and to the inability of the "classical" (id est, conservative) theatre to react to these injustices.

9 Similar observations about this nihilism characteristic of the 1990s makes for example the writer Adrian Schiop, with reference to the ideological landmarks of the generation 2000 in literature. In a way, things inspire one another - Vera Ion, for example, a playwright launched by dramAcum, is also a generation 2000 poet (initially under the pseudonym Zvera Ion). 
GENEALOGY OF POLITICAL THEATRE IN POST-SOCIALISM. FROM THE ANTI-“SYSTEM” NIHILISM TO THE ANTI-CAPITALIST LEFT

\section{The birth of the leftist critique of the capitalist system, in three stages}

From my point of view, which largely coincides with Iulia Popovici's observations (2016, but also in Cîntec, 2019), the essential moments for the left-wing politicization of anti-system criticism in the local theatre would be three: the anti-gentrification community theatre projects in Rahova-Uranus (2006-2007); the performance against the Roşia Montană mining operation Roșia Montană On the Physical Line and On the Political Line (2010); the documentation, production and touring in mining cities of the project Under the Ground - Jiu Valley After 1989 (2011-2012). Not coincidentally, the three moments frame the transition from the triumphalist enthusiasm of entering the European Union to the anti-austerity protests in the post-global financial crisis of 2009-2010. And this period coincides with the local (re)birth of independent anti-capitalist leftist movements (see the appearance of Indimedia or CritcAtac, according to T,ichindeleanu, 2016; Cistelecan, 2019). Let's take them one at a time.

The projects carried out by a multidisciplinary group of artists ${ }^{10}$ (directors, playwrights, actors, visual artists, musicians, choreographers, etc.) in the perimeter of Rahova-Uranus-Sabinelor in Bucharest started in 2006 and had a rather sinuous trajectory that has culminated in the emancipation of some members of the neighbourhood community, who managed their own cultural association and collaborated with various artists in educational and artistic programs. I will not describe in detail this development that spans over at least a decade, not only because the space of the present text does not allow it, but especially because there are already at least two complementary perspectives from within, one of them belonging to me (Georgescu, 2013; Schwartz, 2016). In short, the projects included both artistic activities (theatre projects about the social issues of the neighbourhood community, concerts with the children in the neighbourhood, etc.) as well as civic and political activities (from social assistance for the people in the neighbourhood and mediation of their relationship with the mayor's office, to debates and public protests).

Although it did not intend to be neither (exclusively) theatre nor (explicitly) political, it was most likely the first left-wing, militant, political project after 1989. From the very beginning, after a first stage of research in the area and interaction with the people in the neighbourhood, it became obvious to many of the artists involved that the inhabitants (an ethnically diverse community -

10 Offensive of Generosity Initiative - co-founders: Miruna Dinu, Maria Drăghici, Irina Gâdiuță, Bogdan Georgescu, Vera Ion, Ioana Păun, David Schwartz. 
Roma and non-Roma, but mostly from the working class and with limited access to education) are facing major social problems, on at least two levels: first, the imminence of evictions under the pretext of restitution of nationalized buildings ${ }^{11}$ in the context of the gentrification of the area, located near the centre of Bucharest. Secondly, the systemic racism that hinders both their access to the labour market and the access to social services, however precarious. Thus, from the first theatre projects in the neighbourhood park (held in 2006), the artistic endeavour was subsumed to a political purpose - to facilitate the community's access to self-representation, with the explicit task of supporting their fight against largely illegal evictions. The project was a fundamental one for the evolution of the political theatre from many points of view.

First of all, it was a real school for a good part of the artists who will do later critical-political theatre - from the co-founding director, Bogdan Georgescu, to the director and scenographer Irina Gâdiuță, the playwright Mihaela Michailov and to the actresses and actors, some of whom will also start political theatre projects, such as Alexandru Fifea, Alice Monica Marinescu, Andrei Șerban. From my personal point of view, my left-wing politicization is primarily related to the direct confrontation with this textbook about the functioning of capitalism in its neoliberal version. In Rahova-Uranus, under the pretext of legality and restoration of "historical justice", class oppression and widespread racism were complemented to facilitate the privatization of public housing. The unfolding of this process, the acquaintance and friendship with the people who suffer directly and severely from these actions, worked for me (but not only) as a process of consciousness awakening, which made me increasingly interested in leftist theory and understanding the world from this perspective, but also looking differently at the stakes and potential of the theatrical act. Secondly, at the level of the themes addressed in the theatre performances, at least the production Outside!12 brought a new, I would say, perspective in the local theatrical space: not only a critical transposition of the concrete social issue (the eviction from a public dwelling of poor working class family, who does not afford housing at the market price), but the questioning itself of the morality and justice that the concept of restitutio in integrum implies regarding the properties nationalized during the socialist period. The moment is important because it marks the emergence in the theatrical field of a thinking gap that

\footnotetext{
11 There is a rich literature on restitutio in integrum as a pretext for the privatization of the public housing fund, both in Romania and in other countries in Eastern Europe (for example Poland). I described in detail the process in my PhD thesis (Schwartz, 2016).

12 Text: Mihaela Michailov; scenography: Andrada Chiriac; with: Florina Gleznea, Alice Monica Marinescu, Maria Obretin, Sorin Poamă, Alec Secăreanu, Andrei Șerban. Premiere: September 2007, part of the production "Build Your Community!".
} 


\section{GENEALOGY OF POLITICAL THEATRE IN POST-SOCIALISM. FROM THE ANTI-“SYSTEM" NIHILISM TO THE ANTI-CAPITALIST LEFT}

had barely emerged in other theoretical or artistic fields locally: the courage to step out of the compulsory anti-communist paradigm and to question the justice of the mechanisms of diminishing public property and concentration of private property. Finally, thirdly, the Rahova-Uranus experience marks the first example (and so far one of only two, together with the $4^{\text {th }} A g e^{13}$ program at "Moses Rosen" residential home) of involving non-professional artists to participate in political theatre projects for longer periods; and the only one in which a group of women from the neighbourhood, directly affected by the social-political issues they presented on stage, has long assumed the coordination of artistic-political-educational activities (theatre performances, workshops for children, public protests, etc.).

The second important project for the genesis of the anti-capitalist political theatre is the performance of the dramAcum group from 2010, Roșia Montana, on the physical and political lines ${ }^{14}$. If, from the point of view of the work process, the show consolidates the direction started by dramAcum members (the period of documentation as a mandatory first stage, followed by a process of fictionalization, and the development of the text in rehearsals with the acting team), the show comes with positioning a more radical policy not just a deafening rebellion against the system, as in the early 2000s, but a project already undertaken "against Gold Corporation" and "against a state that is abandoning its citizens." Thus, the group of artists and actors express themselves explicitly anti-corporate politically and against a complicit state with international mining companies. The show has important aestheticpolitical merits as well - scenes that perfectly portray the dimension of social destruction that the aggressive and invasive corporation produces in a village dominated by poverty and family relations, however dysfunctional (see also Michailov, 2013). But perhaps the most significant contribution to the history of local political theatre is another: this show, more than any other, shows the limits of the much-touted "freedom of expression" in the peripheral capitalist system. Although it has had undeniable critical success (it was selected at national and international festivals; it received the prize for best performance at the Romanian Drama Festival in Timișoara, etc.), the show will be sabotaged

\footnotetext{
$134^{\text {th }}$ Age - community art program for the elderly, started in 2009, which continues today at the "Amalia and chief rabbi Dr. Moses Rosen" residential home in Bucharest, coordinated by Paul Dunca, Alice Monica Marinescu, Katia Pascariu, Mihaela Michailov, David Schwartz.

14 Directed by: Gianina Cărbunariu, Andreea Vălean, Radu Apostol; text: Peca Ștefan, Gianina Cărbunariu, Andreea Vălean; with: Csilla Albert, András Buzási, Loránd Farkas, Csongor Kölö, Levente Molnár, Cristina Toma; scenography, video, light design: Andu Dumitrescu; choreography: Florin Fieroiu; soundtrack: Bogdan Burlăcianu; translation: Péter Demény; co-production: Hungarian State Theatre Cluj-Napoca, dramAcum.
} 
and finally buried by its own producer - the Hungarian State Theater in Cluj. The sabotage took place on multiple levels: from the refusal of the producer theatre, under different minor pretexts, to participate in international festivals, but also to the Fân-Fest protest festival in Roșia-Montana (where the artistic team eventually made a show-reading, read by the directors themselves); up to the refusal to schedule the show and even the refusal to sell tickets at the scheduled performances (Cărbunariu et al., 2011). In short, the show was censored and eventually cancelled. Thus, the merit of the whole project is that of devouring, in all their splendour, the mechanisms of censorship in capitalism and of relativizing and putting in a new perspective, once again, the socialist experience. Given that one of the most commonly used arguments against real socialism is that it has undermined freedom of expression and freedom of opinion, the public sphere is now facing the first scandal of a theatrical show produced in full "democracy", de facto banned, because it criticized and disturbed an exponent of international capital.

Finally, the third and last artistic-political endeavour that I consider representative for this stage is, again, one in which I was directly involved. Under the Ground - Jiu Valley After 198915, from the start, set out to document the life and problems of the mining communities, decisively affected by privatization, and to restore the dignity of a social category stigmatized in the post-socialist period. The project consisted of conducting a series of documentary interviews, interdisciplinary workshops for children and adolescents in the Jiu Valley and a theatre production about the life and work of miners. The resulting performance had its premiere in Bucharest in May 2012 and had performances in 11 (former) mining locations in Hunedoara and Maramureș. Again, more interesting than designing and making the show itself was the tour experience. The idea was not necessarily new - in 2009, Bogdan Georgescu coordinated the project Touring in the Countryside, which aimed to contribute to the recovery and reconversion of cultural houses in the rural area into socio-cultural spaces for the local audience. But in the case of Under the Ground, being a performance with an important historical dimension, which discusses the rise and fall of a professional category and of a whole geographical space, the approach gained different valences and led to another forming experience. First of all, it was extremely difficult to ensure the participation of miners or former miners in the production. On the one hand, because many had already left the area (they had returned to the countryside or had gone abroad). On the other hand,

15 Concept: Mihaela Michailov and David Schwartz; with: Alice Monica Marinescu, Katia Pascariu, Alexandru Potocean, Andrei Șerban; music: Bobo Burlăcianu; scenography: Adrian Cristea; video documentary: Vlad Petri. This project will also be briefly described in this article. A full exposition of the whole approach can be found in Schwartz, 2016, Part II, Chapter 3. 


\section{GENEALOGY OF POLITICAL THEATRE IN POST-SOCIALISM. FROM THE ANTI-“SYSTEM" NIHILISM TO THE ANTI-CAPITALIST LEFT}

because people were particularly sceptical of an invitation to the theatre. In most of the localities of the Jiu Valley or the Baia Mare mining basin, areas with extraordinary cultural effervescence during the socialist period, when theatres in the country toured constantly, in 2012 the younger people had never seen a drama theatre performance, and the elderly hadn't seen theatre since before 1989. Thus, it was no surprise that an 80-year-old spectator from the village of Tăuții Măgherăuș exclaimed at the end of a performance: "Since 1989 there has been no such great truth!". The lack of familiarity with theatrical performances led, when the spectators allowed themselves to enter the room, to a kind of spontaneous interaction - people were talking during the performance, talking with the actors and actresses, who had to interrupt their preset course, to answer them and to integrate public interventions. The participation of the audience in the performance took place naturally, without programming, beyond the "participatory" pretensions of the contemporary theatre, in a dialogue in which the spectators felt really empowered to ask, question, criticize or sing miners' songs together with the actors. Thus, we recovered a form of popular theatre performance, in which people felt not only that their stories and perspectives were transmitted, but that they were entitled to intervene and change the course of events on the stage (for a more detailed description see also Michailov, 2014).

The experience of working on Under the Ground, from the documentation process to the touring, was also a kind of artistic, but especially political, maturity exam, of what would become the core of the future political theatre projects started by our collective. A landmark of fair reporting to the recent past, to the stories of the people we interact with and to the consistency of political stakes, to which we return whenever we feel in difficulty in one way or another ${ }^{16}$. For the ordinary theatre audience, from Bucharest but also from other cities where we performed in (Cluj, Iași, Galați, Timișoara, etc.), the

\footnotetext{
16 The team of actresses and actors from Under the Ground, joined by Alexandru Fifea, has formed in the last 8 years a group in which we share relatively common ideas about theatre and politics, whose origins are found in working on a few projects that have shaped our conceptions (first of all, the Rahova-Uranus projects, the $4^{\text {th }}$ Age program and Under the Ground). These experiences have welded a team that is working together and trying to undermine ordinary hierarchies in theatre projects - not in the sense that "everyone does everything", but in the idea that everyone is equally responsible and equally conscious and assumed in the message transmitted by the performance. This collective takeover of the show, which is an important part of our artistic program, is not necessarily common even in the local leftist political theatre. The only political theatre team that works similarly, in an even more radical and exclusivist manner, is from the Republic of Moldova - the one coagulated around Nicoleta Esinencu, Nora Dorogan and Doriana Talmazan at the Kishinev Laundry-Theatre.
} 
production marked one of the first meetings with a different representation of the socialist period. This is not an idealized representation - there is in the performance a monologue of a dissident miner, describing the hardness of the mine work and the extremely difficult situation of the miners before 1989, a miner who also protested and was investigated by Securitate in 1977. It is about a balanced perspective, able to evaluate the problems and the solutions of both systems, from the point of view of some of the great losers of capitalism everywhere - mine workers and their families ${ }^{17}$. A perspective that turns over the mirror and re-focuses on the worker as a subject of history. The 20072013 period was, at least for some of the artists interested in various forms of socially-aware theatre (called in different, successive formulas - community theatre, active art, documentary theatre, political theatre, etc.), a period of discovery and consolidation of the political direction, against the background of the significant change in the material conditions ${ }^{18}$ (the austerity program implemented by the Băsescu-Boc government brought, in the logic of the social disaster from all the areas that depended on public resources, the drastic decrease of the funds for the independent culture), a period in which most of the artists survived from non-artistic work or with family support and worked almost for free. Only a few years after joining the European Union, which should have marked the terminus of the "triumphal march towards capitalism", the economic situation became almost as difficult as during the 1990s. However, this direct confrontation with the logic and consequences of the economic crisis awakened and developed the political consciousness of a significant part of the leftist intellectual field. This process created an intellectual and activist effervescence among artists concerned with socially-aware theatre and was to

17 Not coincidentally, miners are the favorite subject of many leftist artists, locally and internationally from paintings by Lazăr Zin or Mina Bick Wepper to Emile Zola's novel, Germinal, and from documentary film such as Harlan Country U.S.A. to Herbert Biberman or Ken Loach's films.

18 It would be interesting to make a parallel study on the evolution of the social-political theatre in the Republic of Moldova. On the one hand, the evolution of the playwright and director Nicoleta Esinencu, who belongs to the same generation as the dramAcum members and whose path somehow condenses the evolution of the Romanian political theatre - from the nihilistic and antiestablishment (dis)articulation, to an explicit criticism of capitalism and neoliberalism from queerfeminist intersectional positions. On the other hand, the evolution of other artists of her generation (for example, Luminița Țâcu), who make performances with social ambitions almost exclusively at the request of international NGOs, on the topics on their agenda. Both because of a relatively common history (that of the dismantling of public resources and goods in postsocialism), as well as, probably, of certain coincidences (Ovidiu Tichindeleanu's activity in Kishinev or the collaboration between the Laundry-Theatre and Romanian artists - Bogdan Georgescu, Alice Monica Marinescu, myself), it would seem that the turning point for the direct criticism of capitalism also comes with regard to Esinencu's team in 2012-2013. 
GENEALOGY OF POLITICAL THEATRE IN POST-SOCIALISM. FROM THE ANTI-“SYSTEM" NIHILISM TO THE ANTI-CAPITALIST LEFT

inspire the emergence, in 2013, of the Political Art Gazette and the consolidation of an annual Political Theatre Season (which really took place every year, starting with 2013, even when resources were very limited).

\section{The explosion of the social theatre}

The development of the theatre with social stakes or aspirations after 2012 is so diverse and branched that it could hardly be properly covered even in a volume. Of course, much of the resulting projects, artistic venues, collectives and performances assume a social role - to draw attention to various social issues, not necessarily politically defined and not necessarily critical to the capitalist order. However, the criticism of the system is evident through the accumulation, through the multitude of revolted performances, on subjects of the most diverse, both with a more general character and with very specific issues: structuring gender roles, sexual identity and oppression of LGBT + people, Roma status and systemic racism, the Romanian-Hungarian inter-ethnic relations, the persecution of the Jews and the Roma during the fascist period, slavery, bullying, body-shaming, the situation of refugees, the condition of the immigrant workers in Romania, the denunciation of the anti-abortion counselling, the exploitation of the multinational corporations, shows performed with and for incarcerated persons, elders who recount their experiences on stage and critically analyse the recent history, the condition of migrant women and the lives of children left at home, the situation of construction workers or the situation of independent artists. And the list can go on. In this effervescence of the theatre with social-political aspirations, we distinguish a series of artists and collectives who frontally and directly criticize the structural problems of capitalism, generally from two complementary angles: one focused on labour and ownership relations specific of the new economic and social system; the other from an intersectional, identity-cantered approach, which explains how the mechanisms of oppression of different subaltern groups are articulated.

Of the first category, the most consistent is again Gianina Cărbunariu, who has written and directed several performances in recent years discussing the development dynamics of the capitalist city, with the inherent social and ethnic class segregation (Sibiu Tiger, a dramAcum production, 2012), the land grabbing practiced by Western multinationals in Romania (For Sale, Odeon Theatre, 2014) or the exploitation of Romanian workers in Germany (Do You Speak Silence?, "Radu Stanca" National Theatre, 2017). Cărbunariu is probably the local director and playwright most concerned with the critical analysis of 
the devastating effects of capitalist mechanisms and of the centre-periphery dynamics in post-socialism (an opinion also shared by Iulia Popovici, who makes a detailed study of Cărbunariu's performances from this perspective in Cîntec, 2019). Further, other projects of artists and collectives who worked in dramAcum or Rahova-Uranus should be mentioned in the same direction. The projects generated by the evicted women from Rahova-Uranus (Gabriela Dumitru, Cristina Eremia, Cornelia Ioniță), in collaboration with various artists, are all focused on the problems of precarious housing and real estate speculation, but with references to racism, the dysfunctionality of social services and the condition of the poorest workers (Without Support, coordinator Bogdan Georgescu, 2012, La Harneală, directed by Mihai Lukács, 2014, The Subjective Museum of Housing, directed by Andrei Șerban, 2016). Bogdan Georgescu's performance ForTheWin $(02 \mathrm{G}, 2012)$ discusses the condition of workers exploited in corporations, starting from the real case of a young woman who worked until she died of burnout. Mihaela Michailov and Radu Apostol's performance, Offline Family (2013), made with children from a district school in Bucharest, speaks about the economic migration and the situation of children and elderly people left at home. Finally, a new generation of artists occasionally addresses similar topics - degradation of living conditions, labour relations and the situation of workers in post-socialism - for example, Raul Coldea and Petro Ionescu in Provisional (Reactor Cluj, 2015) and Refugees (Reactor Cluj, 2016) or Catinca Drăgănescu in Rovegan (2016).

A sub-category of the approaches to the change (perceived in all these examples as negative) of labour, property and housing relations, which emerged a little more recently, is represented by performances that try an historical approach, inevitably oriented more towards a political criticism of the postsocialist "transition" as a system. I worked directly in two of them: '90, (Macaz Theatre-Coop, 2017, written with the actors Alex Fifea, Alice Monica Marinescu, Katia Pascariu, Alexandru Potocean and Andrei Șerban), which starts from our family histories in order to perform an x-ray of the traumatic effects of social transformations after 1990; and The Cluj Miracle (Reactor, 2017, text by Petro Ionescu), in which, starting with the documentation of the Caritas Ponzi scheme from the '90s, we follow the polarization and financialization of the postsocialist society. In the same subcategory can be integrated two productions that work with non-professionals performing their own story: Tzuhaus (Macaz Theater Coop \& Reciproca, 2017), a show directed by Lorand Maxim, in which Vlad-Florin Bălteanu, a former inmate, restores his personal route, from easyto-earn entrepreneurial dreams to the condition of a person with a criminal record; and The Ballads of Memory (Reactor, 2019), coordinated by the Moldovan 
playwright Nicoleta Esinencu, with whom Raul Coldea also collaborates, in which Ionela Pop, a pensioner from Cluj, tells the history of herself and her friends, the history of the social destruction and economic decline of the last 30 years.

In the second category, of performances cantered on how the capitalist society oppresses or marginalizes different bodies and identities, the representative productions, although at first glance numerous, are significantly reduced if we apply somewhat stricter intersectional criteria, which also includes the dimension of class. Thus, the most relevant examples are, in my opinion, the performances of the Roma feminist theatre collective Giuvlipen (set up by the actresses Mihaela Drăgan and Zita Moldovan together with the director Mihai Lukács in 2014). Of their productions, Who killed Szomna Grancsa? (2017, directed by Mihai Lukács) most precisely articulates a systemic criticism, from a Roma feminist perspective, which includes racism in the educational system, poverty and precariousness of the rural environment, patriarchal prejudices both in the Roma community and among the majority and the criticism of mass-media sensationalism. Another show with remarkable success in revealing the overlaps and intersections of various forms of violence - against queer people, against poor people, against women, against those who have bodies that do not comply with binary gender norms - is Bold (Negreșită), initiated by Carolina Vozian (Macaz Theatre Coop, 2018). Finally, two, somewhat complementary, theatrical examples on the condition of emigrants and refugees from the global south, which aim to underline the direct links between the consequences of the unstoppable race for capital accumulation (war, climate crisis) and dislocation of non-European populations, as well as the racism subsumed by these processes, are We Were Not Born in the Right Place (by Alice Monica Marinescu and David Schwartz, 2013), and Guilty (respectively) (Bezna collective, 2018).

Finally, there is a special performance in this whole landscape, one that I worked on, in a large and multi-disciplinary team - actors, playwrights, choreographers, historians, journalists. It is What We Would Be If We Knew - A Protesting Political Fairy ${ }^{19}$. Made in 2015, at the end of a year of documentation, the performance is probably the most ambitious political project of the leftist theatre - it aims to illustrate a condensed history of workers' protests covering a long time, practically the whole XXth century - and counterpointed by elements of political utopia inspired by Neagu-Negulescu' Arimania ${ }^{20}$. Probably the result,

19 The team: Mădălina Brândușe, Paul Dunca, Adela Iacoban, Alice Monica Marinescu, Mihaela Michailov, Katia Pascariu, Alexandru Potocean, Cătălin Rulea, David Schwartz, Andrei Șerban, Ionuț Sociu, Marius-Bogdan Tudor. Production: O2G Association, 2015.

20 Utopia written by the union activist Iuliu Neagu-Negulescu in 1921, while in prison for political activity, republished, after the premiere of What We Would Be If We Knew, by the Free Pages Publishing House (2018). 
in terms of artistic force at least, did not rise to the level of the premises, sinning through an approach maybe too didactic or too austere and cumbersome. ${ }^{21}$ But the show marked a unique moment for now: a project undertaken collectively by a group of cultural workers who openly and unhesitatingly reveal their adherence to leftist ideas and the claim of the history of protests and political struggles won by the working class.

The performances listed are quite different from all points of view verbatim-style documentary approaches and Brechtian stylistics, classical realism and various forms of poetic realism; working with the personal stories of the creative team and projects that include oppressed people who tell their perspectives and even initiate some performances; performances initiated by the authors-playwrights and collective projects in which the director is not mentioned; independent productions with zero budget and projects with consistent international financing. All these approaches express the diversity and internal plurivalences that the critical political theatre has acquired in the capitalist order in the last ten years. All the more so as I operated a severe selection, on the one hand refusing to mention similar projects going in the same direction, on the other hand on the objective criterion of articulating at least an implicit criticism of the functioning of local and/or global capitalism (and not just punctual criticism of various norms or social dysfunctions), but also on the subjective, inevitable criterion of the performances that are known to me. Although in the local theatrical and cultural context the assumed social-political theatre still occupies a subordinate position, within which the theatre critical of capitalism hardly represents a niche, its extent and degree of visibility in the last 20 years have increased exponentially. Under these conditions, in order to formulate at least a hypothesis about the conditions of production and reproduction of this theatre, we must lean, at least synthetically, on the history of resources and means of production - financing and producing institutions, international partners and collaborators, publications and cultural supporters, etc.

\section{The apparatus and the conditions of production - where does the money come from and how does the discourse spread?}

As mentioned above, interactions with Western culture (and certain policies) were a decisive factor, at least for the emergence of the first elements of critical social theatre. Andreea Vălean, Gianina Cărbunariu, Mihaela Michailov

\footnotetext{
21 For the controversies, both aesthetical and political, and for a wider discussion about the history and politics in theatre at that time, see Popovici 2015, Iancu 2015, Lazăr 2015.
} 
had playwriting residencies at the Royal Court in London, Radu Apostol and Bogdan Georgescu had fellowships at the Cornerstone Community Theatre Institute in Los Angeles, dramAcum was initially funded by the Rațiu Foundation in London, and The Open Society Institute and the Foundation for an Open Society also funded projects to support contemporary Romanian dramaturgy. Although it is obvious that the texts, performances and social media projects of the respective artists and collectives started from personal, deeply subjective, emotional and intellectual responses to the violent objective realities in which they lived, the aesthetic articulation and a certain political direction were certainly influenced by meeting with the theatrical culture and also with a certain set of values and perceptions about the world of Western "progressive" institutions. In the absence of any landmarks about the tradition and history of the local social-political theatre, it was natural for inspiration and influences, both aesthetically and ideologically, to come from international projects within reach. The use of formulas such as community theatre (performed with a community affected by and/or constituted around a specific problem) or the verbatim technique (word-for-word transcription and reproduction of pre-existing materials, usually interviews) should not be put on account of any self-colonization or "cultural imperialism," as Western theatre critics have occasionally accused hastily (Haydon, 2013). They must be understood as syncretic responses to the structural political problems that the periphery of the global capitalist system faces, one of the main problems being precisely the erasure of the history of their own movements and actions of political resistance. If, in an effective process of self-colonization, the history of the local left and the history of proletarian art are minimized and forgotten ${ }^{22}$, the political theatre has two solutions: to take it again from scratch or to draw inspiration from the accessible models - obviously largely Western, in a world dominated culturally, financially and politically by Western countries.

Beyond the aesthetic dimension, speaking about material conditions, the Western funding structures (the ones mentioned above, but also ProHelvetia, for example) have played an important role in the survival of the initial sociallyengaged theatre projects, especially in the dimensions that are not related to the production per se (drama competitions, text development workshops, drama and community theatre workshops, etc.). Local state theatres have been involved occasionally and usually for very short periods. The only notable exception is the Small Theatre in Bucharest, which dedicated a hall (the Very Small Theatre) to "experimental" projects, but especially to contemporary theatre performances

22 See also Țichindeleanu's (2016) theory of anti-communism as a typical form of articulation of selfcolonization in the local context. 
of Romanian drama (here were performed some of the most important productions with social-political stakes - of the dramAcum members, such as mady-baby.edu, Vitamins or Offline Family).

Things have changed substantially from two directions, starting with 2006-2007. First, a functional financing structure for independent projects appeared - the Administration of the National Cultural Fund (AFCN; see also Iulia Popovici's opinion in Ernu, 2017), a structure that supported, through assumed directions and priorities, cultural projects with social stakes. This process led to the multiplication and serious development of social-political theatre projects, and the shift of priorities towards some more focused on socialpolitical-educational contributions (in particular the support for production, the support for the involvement of the culturally disadvantaged categories of audience and the support for contemporary Romanian dramaturgy) gave a new boost to the leftist political theatre after 2014. Secondly, one of the most involved artists in the critical political theatre, Gianina Cărbunariu, gained notoriety and a remarkable success at international level (her texts were translated and staged in many languages on three continents; she was invited to important festivals such as Avignon, etc.). This international success has attracted, as it is always the case in peripheral areas, the recognition of the local theatre community, recognition that has materialized in two UNITER awards and a third nomination, as well as in the multiplication of Cărbunariu's collaborations with state theatres. Once the breach was opened, shows with very sensitive political topics, with a consistent critical dimension, took place - of course rather occasionally - in public theatres. In parallel, the increase of the AFCN budget and the professionalization of some artists and artistic collectives in project management and the writing of applications for grants have led to the development of long-term program strategies (including by attracting European funds). The increase of public funds for projects with a critical political direction coincided with the partial withdrawal of international funding (less funds for the culture of EU countries). This phenomenon also coincided with the radicalization of political discourse in a more critical direction towards Western capital and structures of domination. If in the state theatres there are still serious limits regarding acceptable radicalism (as the example of the Roşia Montană... performance has shown), the non-reimbursable financing only orients the general direction by establishing the objectives and priorities of the programs, but it does not involve, until this moment, absolutely no form of artistic or political censorship.

After 2014, the social-political theatre has become a constant in spaces such as Replika Educational Theatre Centre in Bucharest or the Paintbrush Factory and Reactor in Cluj, and in 2016 a group of artists and activists of which I was a part of established MACAZ Bar Coop Theatre, the first local venue since 1989 
dedicated to political theatre, a theatre cooperative and bar, organized on nonhierarchical, intersectional and anti-capitalist principles. ${ }^{23}$ MACAZ has been operating for three years and has been closed for a reason typical for the political context (the owner's refusal to extend the contract for the venue). During this period, it (co)produced over 20 performances, many of which are mentioned in this article, and co-organized/hosted an annual season of political theatre, political theatre workshops, public debates and discussions on the role of political art or the situation of the workers from the independent cultural sector.

Beyond the relative openness of the state theatres, the self-support through non-reimbursable financing mechanisms and the appearance of specific venues and festivals (in the first place, Temps d'Images in Cluj, which also held for 10 years, until 2018), the left-wing political theatre projects were supported by few critics, but who wrote (write) in some of the most respected local publications - Iulia Popovici in Observator Cultural, Oana Stoica in Dilema Veche and Scena9. The performances, of course, attracted the attention of the rather small community of the independent intellectual left, and the important artists were constantly invited on radio shows or they gave written interviews. But I would say that an important means of spreading and developing the local political theatre, which has led to the popularization of left ideas among artists, was the formal and non-formal education of the artists themselves. At least since 2007, some of the artists involved in political theatre (Cărbunariu, Georgescu, Michailov, Schwartz, Marinescu, Pascariu, Serban) have held relatively constant workshops, courses and seminars for students or young graduates of performing arts, on multiple forms of social theatre, in different contexts (academic, festivals, independent initiatives): at the theatre faculties in Bucharest (UNATC), Cluj and Sibiu; within the festivals such as Temps d'Images Cluj, the Romanian Playwriting Festival Timișoara, the Alexandria Festival, the Telciu Summer School; in independent projects such as Focus Atelier, Fresh Start, the School of Political Theatre.

\section{Present and future: between the need for institutionalization and the delimitation of the "militant" theatre on the right}

All the structural and institutional factors listed above have contributed, in one measure or another, to the development of local political theatre, in particular, but not exclusively, in Bucharest and Cluj. However, at least for some of us, especially in the case of our political theatre team (the one consolidated

${ }^{23}$ For a broad description of the history of the project, see Dana Andrei, "The measure of our political identity lies in our actions", in IDEA. Art + society, no. 54, 2019. 
from common experiences in projects such as Under the Ground and responsible for the theatre component at MACAZ), the prospects are not so sure. The precariousness of independent artists, which has been written about in recent years (see Popovici in Ernu, 2017), makes some of them live from project to project, accept jobs that they do not want or work on artistic projects that do not represent them.

In our case, we tried to build a relatively stable group, of people working together, even if in different and complementary formulas, and who share not only an artistic direction, but also a political belief; however, the lack of financial and institutional stability has the potential to undermine the unity of the group. Another problem is the chronic lack of professionals in the fields related to the artistic act - especially management, production, technicians and PR. All these needs, felt by the majority of artists and collectives working independently, underline the growing need for institutionalization. Without institutions with constant and secure resources, all the effervescence of the leftist political theatre risks being consumed in less than a generation (I think the same is true for the production of critical theory, visual arts or anything else). In the context in which professional, material or symbolic recognition for the militant theatre does not come often or easily, no matter how powerful the dedication for the cause, the decisive factor becomes safety and predictability - the guarantee of long-term continuity and development.

At the same time, in recent years, the paradoxical, but not quite surprising, phenomenon that I wrote about in the first part of the present material is also noted: the political, militant theatre is again interesting and attractive for the establishment. Former PSD leader Liviu Dragnea's speech pastiches (or the fetishization of \#resist protests, obviously political elements) are appearing on stage at Bulandra Theatre or the National Theatre in Bucharest. They should point out that the conservative intelligentsia, at least the one from the theatre, came out of the "ivory tower" and threw itself into the political arena. In a way this is the case - the right-wing radicalization of the middle class in recent years, a radicalization that culminated in the virulent anti-poor, anti-elderly, against the "socially-assisted" attitudes, codified in anti-PSD activism and essentialized in slogans such as "Down with the Red Plague", "Down with Corruption!", "F*** PSD", got, with little delay, into the world of theatre. Which, in a way, is good news: the conflict between social classes is no longer overshadowed and sublimated in aestheticizing discourses on "art for art's sake" and "general human problems", but is expressed directly, in the confrontation between the leftist political theatre and the one newly engaged to the right. 


\section{GENEALOGY OF POLITICAL THEATRE IN POST-SOCIALISM. FROM THE ANTI-“SYSTEM" NIHILISM TO THE ANTI-CAPITALIST LEFT}

So, at the moment, the leftist militant theatre is somehow facing a new attempt - to compete directly not with a speech that disqualifies militant art as bad or even non-art, but with a militant alternative discourse, in fact the opposite, which has infinitely richer financial and institutional resources. In this context, the only chance remains the struggle to conquer new resources (institutions, financing mechanisms, means of promotion). A very important stake in this direction is to win new categories of audiences, especially since the polls show that in fact the number of spectators attending theatre is actually very small in relation to the total number of the population, even in the big cities.

However, in 2019 some steps have been taken in this regard. For our group, one possible direction is to initiate collaboration with the trade union movement. The unions have been traditional collaborators of the political theatre since the experiences of Brecht or Piscator (Brecht, 1988; Piscator, 1966). And in the local context, the trade union movement is also in the process of reinventing itself. The unions still have an important network of members at national level, but they need means of promotion and alternative education. Thus, they can ensure an audience with high potential to be receptive to the values of the left. A first step in this direction was the Universal Worker ${ }^{24}$ project, which included documentation, participatory theatre workshops and a performance about the lives and labour of workers in retail multinationals. Another very important direction, which actually develops the direction started by Touring in the Countryside or Under the Ground, is the production of theatre performances in small towns and rural areas. And in this regard, the year 2019 was an interesting one - the County Museum of History and Arts in Zalău co-produced, with the important contribution of the historical researcher Valer Simion Cosma, two political theatre performances (given that Zalău is one of the county residences in Romania without a municipal theatre). The two performances, both critical of neoliberal policies, address complementary issues: Factories and Plants ${ }^{25}$ documents the lives of the families of workers at the Armătura Factory and how they were affected by the closing of the factory;

\footnotetext{
24 With: Alice Monica Marinescu, Katia Pascariu, Alexandru Potocean, Andrei Șerban; music and text: Maria Sgârcitu; set design: Irina Gâdiuță; choreography: Carmen Coțofană; dramaturgy and direction: David Schwartz; produced: 02G Association in partnership with Retail Unions Federation.

25 Directed by: Adina Lazăr; dramaturgy: Alexandra Felseghi; set design: Silviu Medeșan; grafica: Paul Muresan; cu: Ioana Chitu, Emanuel Cifor, Lucian Teodor Rus, Simina Seliștean; documentation: Bianca Felseghi, Valer Simion Cosma; assistents: Turian Mihai, Denisa Gordan, Reka Domokos, Catalin Ilies; project manager: Andrei Herța; production: Centre for the Study of Modernity and the Rural World in partnership with the Zalău County Museum of History and Arts.
} 
I Am One of the Lucky Ones ${ }^{26}$ tells the story of the economic migration from the villages in the county of Sălaj. The two shows have already toured in other cities and performed several times in Zalău. The approach of Zalău Museum represents, I think, a model for the political theatre of the left in the future: institutional support; turning to culturally marginalized areas (cities without a state theatre and their surrounding rural localities); winning an audience that has very limited access to the theatre and who can see themselves in the ideas and experiences presented in the shows. In short, expanding the battlefield.

\section{REFERENCES}

Aldulescu, Radu (2012). Cronicile genocidului [The chronicals of the genocide]. Cartea românească. București.

Andrei, Dana (2019) Măsura identității noastre politice stă în acțiunile noastre [The extent of our political identity depends on our actions]. IDEA. Artă+societate, nr. 54.

Apostol, Radu, Gianina Cărbunariu, Peca Ștefan, Andreea Vălean (2011). Despre adevăruri neconvenabile / Despre neadevăruri convenabile - Roşia Montană pe linie fizică şi pe linie politică [About inconvenient truths / About convenient untruths - Roşia Montană - on its material and political course]. Liternet. August 2011. Liternet.ro. (Accessed on 11.12.2019).

Apostol, Radu (2018). Teatru social: perspective asupra rolului teatrului în raport cu societatea [Social theatre: Perspectives on the role of theatre in relation to society]. U.N.A.T.C. Press. București.

Ban, Cornel (2014) Dependență și dezvoltare. Economia politică a capitalismului românesc [Dependence and Development. The Political Economy of Romanian Capitalism]. Editura Tact. Cluj.

Bercovici, Israil (1982). 100 de ani de teatru evreiesc în România [100 years of Jewish theatre in Romania]. Editura Kriterion. București.

Brecht, Bertolt (1988). Brecht on Theatre - A Development of an Aesthetic. Edited and translated by John Willet. Methuen. London.

Cântec, Oltița (Edt.), (2019). Teatrul.ro - 30. Noi nume [Theatre.ro /Teatrul.ro - 30. New names]. Editura Timpul. Iași.

Cistelecan, Alex (2019). De la stânga la stânga. Lecturi critice în câmpul progresist [From left to the left. Critical readings in the forward-thinking realm]. Editura Tact. Cluj.

26 Directed by: Lorand Maxim; with: Oana Hodade, Dániel Láng, Doru Taloș; documentation: Ágota Ábran, Corina Bejinariu, Valer Simion Cosma, Iulia Hossu, Lorand Maxim, Vlad Petri, Anda Pop, Alexandra Voivozeanu; music: Panna Adorjáni, Zsolt Bodoki-Halmen, Dániel Láng; text: Alexandra Voivozeanu; set design: Anda Pop; produced by: County Museum of History and Arts, Zalău. 


\section{GENEALOGY OF POLITICAL THEATRE IN POST-SOCIALISM. FROM THE ANTI-“SYSTEM” NIHILISM TO THE ANTI-CAPITALIST LEFT}

Crăciun, Camelia (2016). Bucureștiul interbelic, centru emergent de cultură idiș [Bucharest between the wars, a thriving centre of Jiddish culture]. The Journal of Jewish history in Romania. No. 1 (16-17): 65-82.

Dobrogeanu-Gherea, Constantin (1956). Studii Critice [Critical studies]. Editura de Stat pentru Literatură și Artă. București.

Ernu, Vasile (2017). Iulia Popovici: Nimeni n-a descoperit, în ultimii 500 de ani, o metodă prin care teatrul, opera sau muzica simfonică să devină profitabile. [Iulia Popovici: Nobody had managed to discover in the past 500 years a method to make theatre, opera or symphonic music become profitable]. Baricada. 24.10.2017. baricada.org. (Accessed on 18.12.2019).

Florian, Radu (1997). Controversele secolului XX [The controversies of the $20^{\text {th }}$ century]. Diogene.

Georgescu, Bogdan (2013). Teatrul comunitar și arta activă. Teză de doctorat. [Community based theatre and active art. Doctoral thesis]. UNATC. București.

Haydon, Andrew (2013). Romania Round-Up. (Theatre). Postcards from the Gods. 26.09.2013. postcardsgods.blogspot.com. (Accessed on 17.12.2019).

Iancu, Cristina-Maria (2019). Condiția textului dramatic românesc după 1989. Teză de doctorat [The condition of the romanian theatrical text following 1989. Doctoral thesis]. Universitatea Babeș-Bolyai. Cluj.

Iancu, Valentina (2015). Ce-am fi dac-am ști [Who would we be if we knew]. Revista Arta. 24.11.2015. revistaarta.ro. (Accessed on 12.12.2019).

Lazăr, Veronica (2015). Direct politic. Note despre spectacolul "Ce-am fi dac-am ști". [Straight-up political. Notes on the play "Who would we be if we knew"]. Academia.edu. (Accessed on 10.12.2019).

Michailov, Mihaela (2013). Capitalismul morților [The capitalism of the dead]. Gazeta de artă politică. 21.02.2013. artapolitica.ro. (Accessed on 12.12.2019).

Michailov, Mihaela (2014). Teatrul spectatorului indecent [The theatre of the indecent viewer]. Gazeta de artă politică. 6.01.2014. artapolitica.ro. (Accessed on 12.12.2019).

Michailov, Mihaela (2015). Orice om pe lumea asta trebuie să aibă un loc unde să doarmă, să mănânce și să se spele [Every human on this planet needs a place to sleep, eat and to wash]. Gazeta de artă politică. 10.12.2015. artapolitica.ro. (Accessed on 12.12.2019).

Michailov Mihaela; David Schwartz (Eds.), (2017). Teatru politic 2009-2017 [Political theatre Teatru 2009-2017]. Editura Tact. Cluj.

Neagu-Negulescu, Iuliu (2018). Arimania sau țara bunei întelegeri [Arimania or the country of well-understanding]. Editura Pagini Libere. Cluj.

Pasti, Vladimir (2006). Noul capitalism românesc [The New Romanian Capitalism]. Polirom. Iași.

Piscator, Erwin (1966). Teatrul Politic [Political Theatre]. Editura Politică. București.

Popescu, Theodor Cristian (2012). Surplus de oameni sau surplus de idei. Pionierii mișcării independente în teatrul românesc post 1989 [Surplus of People or Surplus of Ideas. The Pioneers of the Independent Movement in the Romanian Theatre After 1989]. Editura Eikon. Cluj. 
Popovici, Iulia (2015). Cum se spune povestea stângii românești [How to recount the history of Romanian left]. Observator cultural. Nr. 794. 16.10.2015. Observator cultural.ro. (Accessed on 13.12.2019).

Popovici, Iulia (2017 a). Elefantul din cameră. Ghid despre teatrul independent din România [The elephant in the room. A guide on independent theatre in Romania]. Idea Design \& Print. Cluj.

Popovici, Iulia (2017 b). A Theatre for the Workers, Protest as Performance, and the Political Police as (Art) Historian. A Plea for the Rediscovering of Interwar Peripheries. Studia UBB Dramatica. LXII (2): 69 - 86.

Runcan, Miruna (2010). Un mic regal. Premiera 1998 [A small crown jewel. A Venue 1998]. Liternet. liternet.ro. (Accessed on 10.12.2019).

Schwartz, David (2016). Teatrul perdanților tranziției post-socialiste. Perspective etice și politice. Teză de doctorat [The theatre of the post-socialist transition's disenfranchised. Ethical and political perspectives. Doctoral thesis]. Universitatea Babeș-Bolyai, Cluj.

Țichindeleanu, Ovidiu (2016). Contracultură. Rudimente de filosofie critică [Counterculture. Rudiments of a critical philosophy]. IDEA Design \& Print. Cluj. 